\title{
New Insights into the Step Pyramid Complex: Klasens' Unpublished Seal Impression Drawings
}

\author{
Tatjana Beuthe \\ Independent Researcher, University College London, UK
}

\begin{abstract}
The Egypt Exploration Society archive contains unpublished pencil drawings by A. Klasens of seal impressions found in the Step Pyramid complex of Saqqara. Digitally inked versions of these drawings are published here for the first time. The seal impressions can be sourced to the Northern Galleries of the complex. The impressions were sealed on clay formerly plastered on a wall, and also bore the imprints of the end(s) of cylinder seals. To explain the presence of seal impressions of Khasekhemwy among the sealings drawn by Klasens, an attempt is made to trace the construction and use history of the Northern Galleries and the contemporary Western Galleries. Possible parallels between some of the Step Pyramid sealings and Beit Khallaf sealings are also discussed.
\end{abstract}

Keywords: Saqqara, Step Pyramid, Northern Galleries, Western Galleries, Khasekhemwy, Netjerikhet, Klasens, sealings, seal impressions

\section{Introduction}

By analysing previously unpublished sealings from the Step Pyramid complex of Saqqara, and examining available published documentation on the appearance and find location of these artefacts, this article sheds new light on the Northern Gallery sealed material, which represents the earliest known incidence of endstamped sealings. The pre-Step Pyramid significance of both the Northern and Western Galleries underneath the complex is also explored in light of the epigraphic evidence provided by the seal impressions. Transliterations and translations of the fragmentary inscriptions are made, and possible parallels for the sealings among seal images known from Beit Khallaf are explored.

\section{The seal impressions}

In this paper, 'sealing' refers to any piece of clay marked with a seal impression. 'Seal impression' or 'impression' refers to the impression left behind by a seal on a clay base, and drawings of these impressions. Frequently, scholars will reconstruct the original carved surface of seals based on evidence from fragmentary impressions. These reconstructions are referred to here as 'seal images'.

Three pages of drawings on tracing paper depicting impressions on clay sealings and labelled in the handwriting of $\mathrm{A}$. Klasens were recently rediscovered by the author in the Egypt Exploration Society (EES) archives of W. B. Emery's excavation papers. The pages were placed in an orange folder in the SAQ-GT.002 archive collection. This folder was labelled: 'EES; Saqqara; Archaic Necropolis; 3505, etc; 3505; 3506; 3507; [in hand of A. Klasens]; \& H. G. Fischer'. One sheet was labelled with the header 'Khasekhemwy', and two others with the header 'Zoser'. The drawings were numbered, and some depicted sealings already published by J.-P. Lauer in 1965. In his book, Lauer stated these drawings were executed for him by Klasens, and they depicted sealings from the Northern Galleries within the Step Pyramid complex. ${ }^{1}$ Table 1 details which of the Klasens

${ }^{1}$ J.-P. Lauer and P. Lacau, La pyramide à degrés, $\mathrm{V}$ (Cairo, 1965), 98. 
drawings were previously published by Lauer. The rows highlighted in grey indicate sealings re-drawn by Klasens that had previously been published by Quibell. ${ }^{2}$ The Klasens reproductions follow modern norms in depicting the hieroglyphs and figurative elements on the sealings as outlines rather than the older convention seen in Quibell's publication, where hieroglyphs are filled in with black. The rendering of the serekh facade in Klasens' Netjerikhet seal impression (6) and the goddess figure in the Netjerikhet seal impression (8) are also much improved compared to the drawings published by Quibell. Klasens' drawings of unpublished sealings and his improved reproductions of the sealings drawn by Quibell are reproduced here for the first time in Figures 1-8, digitally inked from high-quality scans.

Both the sealings highlighted in grey in Table 1 and the ones previously published by Lauer were stated to have been found in the Northern Galleries of the Step Pyramid (see fig. 9). Grain, fruit, and the possible remains of bread were also uncovered in the passage and magazines of this substructure. ${ }^{3}$ Consequently, it is likely that the other five unpublished sealings were also found in the same location. Some of the impressions bear the titulary of the rulers Khasekhemwy and Netjerikhet. Thus, the ensemble of sealings can be provisionally dated to the late Second-early Third Dynasties c. 2610 2566 BCE. $^{4}$

\section{The seal impression drawings}

When formatting Klasens' drawings of the Step Pyramid Northern Galleries for publication, the following norms were followed. As shown in Table 1, the original drawings were found on papers marked 'Khasekhemwy' and 'Zoser'. The original pencil drawings were also numbered by Klasens. To be consistent with modern nomenclature, the 'Zoser' category was renamed 'Netjerikhet', and each drawing is identified with the following nomencla-

\footnotetext{
${ }^{2}$ C. M. Firth and J. E. Quibell, The Step Pyramid, 1 (Cairo, 1935), 141.

${ }^{3}$ Ibid., 141; J.-P. Lauer, La pyramide à degrés, III (Cairo, 1939), 184.

${ }^{4}$ E. Hornung, R. Krauss, and D. A. Warburton, $A n-$ cient Egyptian Chronology (HdO 83; Leiden, 2006), 490.
}

Table 1: Summary of Step Pyramid sealings drawn by Klasens. For clarity and compatibility with modern classifications, sealings under the 'Zoser' heading are referred to as '[Zoser] Netjerikhet'.

\begin{tabular}{|c|c|}
\hline Drawing \# & Published in \\
\hline $\begin{array}{l}\text { Khasekhemwy (1a- } \\
\text { b) }\end{array}$ & Unpublished \\
\hline Khasekhemwy (2) & $\begin{array}{l}\text { Lauer and Lacau, La } \\
\text { pyramide à degrés V, } \\
98 \text { (fig. 179) }\end{array}$ \\
\hline Khasekhemwy (3) & Unpublished \\
\hline Khasekhemwy (4) & $\begin{array}{l}\text { Lauer and Lacau, La } \\
\text { pyramide à degrés V, } \\
98 \text { (fig. 180) }\end{array}$ \\
\hline Khasekhemwy (5) & Unpublished \\
\hline Khasekhemwy (6) & Unpublished \\
\hline $\begin{array}{l}\text { [Zoser }] \text { Netjerikhet } \\
(1)\end{array}$ & $\begin{array}{l}\text { Lauer and Lacau, La } \\
\text { pyramide à degrés V, } \\
98 \text { (fig. 181) }\end{array}$ \\
\hline $\begin{array}{l}\text { [Zoser }] \text { Netjerikhet } \\
(2)\end{array}$ & $\begin{array}{l}\text { Lauer and Lacau, La } \\
\text { pyramide à degrés V, } \\
98 \text { (fig. 182) }\end{array}$ \\
\hline $\begin{array}{l}\text { [Zoser }] \text { Netjerikhet } \\
(3)\end{array}$ & $\begin{array}{l}\text { Lauer and Lacau, La } \\
\text { pyramide à degrés V, } \\
98 \text { (fig. 184) }\end{array}$ \\
\hline $\begin{array}{l}\text { [Zoser] Netjerikhet } \\
(4)\end{array}$ & $\begin{array}{l}\text { Lauer and Lacau, La } \\
\text { pyramide à degrés V, } \\
98 \text { (fig. 185) }\end{array}$ \\
\hline $\begin{array}{l}\text { [Zoser }] \text { Netjerikhet } \\
(5)\end{array}$ & Unpublished \\
\hline $\begin{array}{l}\text { [Zoser] Netjerikhet } \\
(6)\end{array}$ & Unpublished \\
\hline $\begin{array}{l}\text { [Zoser }] \text { Netjerikhet } \\
(7)\end{array}$ & $\begin{array}{l}\text { Lauer and Lacau, La } \\
\text { pyramide à degrés V, } \\
98 \text { (fig. 183) }\end{array}$ \\
\hline $\begin{array}{l}\text { [Zoser] Netjerikhet } \\
(8)\end{array}$ & Unpublished \\
\hline $\begin{array}{l}\text { [Zoser }] \text { Netjerikhet } \\
(9)\end{array}$ & Unpublished \\
\hline $\begin{array}{l}\text { [Zoser } \text { Netjerikhet } \\
(10)\end{array}$ & $\begin{array}{l}\text { Lauer and Lacau, La } \\
\text { pyramide à degrés V, } \\
98 \text { (fig. 186) }\end{array}$ \\
\hline
\end{tabular}


ture: 'Khasekhemwy/Netjerikhet seal impression (original Klasens no.)'. The drawings are reproduced in Figures 1-8. The scale of the drawings was not recorded by Klasens, but an effort has been made to reproduce them in their original size. In this article, the signs on each impression are transliterated and translated from top to bottom and from left to right, in accordance with the reading style established for early impressions and seal images by Kahl. ${ }^{5}$

Since they bear no identifying serekhs, Khasekhemwy seal impression (5), and Netjerikhet seal impression (5) and (9) could possibly be mis-attributed in their naming by Klasens. However, the sealings with no royal imagery may have been found in different discrete locations alongside the sealings bearing the serekhs of these kings. Consequently, the original designations of these sealings have been preserved here.

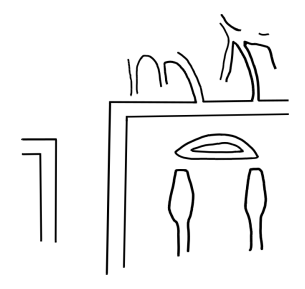

\section{Transliteration: Hr.w-Sth Hej-shm.wj Translation:} Horus-Seth Khasekhemwy

(1a)

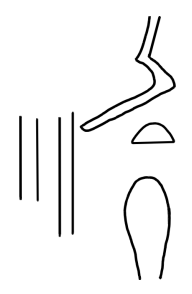

Transliteration:

$m$; [...].t hm

Translation:

[...] servant

(1b)

Fig. 1 Khasekhemwy seal impressions (1a-b). Two impressions found on one sealing. ${ }^{6} \mathrm{An}$ improved reproduction by Klasens of a sealing previously depicted in Firth and Quibell, The Step Pyramid 1, 141 (fig. 22) (courtesy of the Egypt Exploration Society).

${ }^{5}$ J. Kahl, N. Kloth, and U. Zimmermann, Die Inschriften der 3. Dynastie: eine Bestandsaufnahme (苂 56; Wiesbaden, 1996).

${ }^{6}$ Firth and Quibell, The Step Pyramid 1, 142.

${ }^{7}$ The identification of the round hieroglyph as O48 follows the identification of the similar sign on UC57766 given by I. Regulski, Database of Early

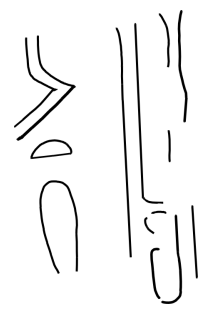

Transliteration:

$m ;[. ..] . t ~ h m$

[Hr.w-Sth $H$ Hj-]shmm[.wj]

Translation:

[...] servant

Horus-Seth Khasekhemwy

Fig. 2 Khasekhemwy seal impression (3). A drawing that likely reproduces an impression from the same seal used to produce the seal impressions shown in Figure 1 (courtesy of the Egypt Exploration Society).

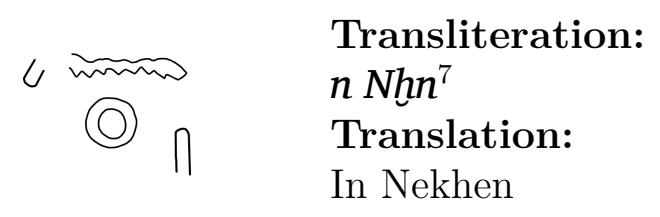

Fig. 3 Khasekhemwy seal impression (5). Fragmentary impression (courtesy of the Egypt Exploration Society).

\section{Find context and appearance of the sealings}

According to Lauer, the seal impressions from the Northern Galleries were found impressed on the clay 'mortar' of blocking walls in the Northern Galleries. These included wall A, which sealed the main corridor of the gallery, and wall $\mathrm{B}$, used to seal one of the side galleries (see fig. 9). ${ }^{11}$ Quibell also mentioned these sealings, describing them as 'blocks of yellow clay' formerly attached to the face of a wall. ${ }^{12}$ The clay is likely to have been taffl, or potters' clay, often used for early sealings in Egypt. ${ }^{13}$ Cloth impressions were present on the clay, and the blocks bore the marks of 'circular grooves'. It was theorized by Quibell that the wet clay was

Dynastic Inscriptions, <https://www1.ivv1.unimuenster.de/litw3/Aegyptologie/index06.htm $>$ accessed 2017.02.5, source no. 3188 .

${ }^{8}$ Transliteration and translation based on Kahl et al., Inschriften der 3. Dynastie, 86-7.

${ }^{9}$ See Footnote 7.

${ }^{10}$ Possible ${ }^{d}$ - $-m r$ title, see I. Regulski, A Palaeographic study of early writing in Egypt (Leuven, 2010), 151.

${ }^{11}$ J.-P. Lauer, La pyramide à degrés, I (Cairo, 1936), 184.

${ }^{12}$ Firth and Quibell, The Step Pyramid 1, 119.

${ }^{13}$ E.-M. Engel and V. Müller, 'Verschlüsse der Frühzeit: Erstellung einer Typologie', GM 178 (2000), 33. 


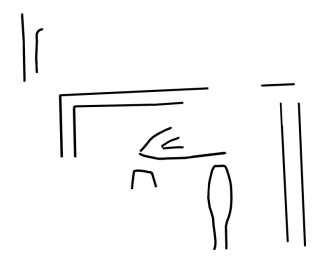

Transliteration: Hr.w[-Sthl] Hijj-shm.wj Translation:

Horus-Seth Khasekhemwy

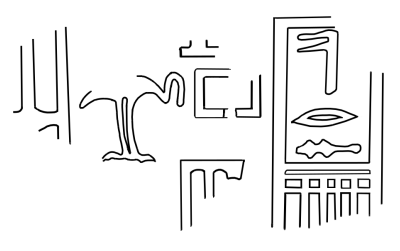

Transliteration: ${ }^{8}$

pr.w dšr

[Hr.w] Ntrr(j)-h.t.t

Translation:

The Red House

Horus Netjerikhet
Fig. 4 Khasekhemwy seal impression (6). Drawing of a seal impression showing a fragmentary serekh of Khasekhemwy. This impression may have been created by the same seal as the one used to produce Figures 1 and 2 (courtesy of the Egypt Exploration Society).

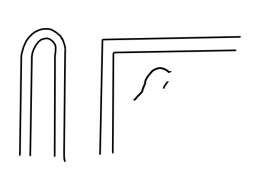

\section{Transliteration: $w s$ \\ Translation:

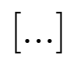

Fig. 5 Netjerikhet seal impression (5). There appear to be no known published parallels for this fragmentary impression (courtesy of the Egypt Exploration Society).

covered with cloth and a 'cylindrical drill' was used to force the cloth into the wet clay, thereby creating the punched impressions. ${ }^{14}$ Given evidence for similar circular impressions on Fourth Dynasty sealings found at Giza, it is likely the Northern Gallery sealings were punched by the round end of a cylinder seal. ${ }^{15}$ Figure 10 depicts an example of an Old Kingdom jar sealing impressed in this fashion.

The Fourth Dynasty sealings from Giza showed evidence that clay sealings were sometimes rolled and end-stamped with the same seal. ${ }^{16}$ The object used to create the circular marks on the Northern Galleries sealings apparently had a diameter of $2.5 \mathrm{~cm} .{ }^{17}$ However, given the wide range of seal impressions attested here and in the Lauer publication, ${ }^{18}$

\footnotetext{
${ }^{14}$ Firth and Quibell, The Step Pyramid 1, 119.

${ }^{15}$ J. S. Nolan, Mud Sealings and Fourth Dynasty Administration at Giza, (PhD Thesis, University of Chicago; Chicago, 2010), 139-40.

${ }^{16}$ Ibid., 143.

${ }^{17}$ Firth and Quibell, The Step Pyramid 1, 119 states that the 'cylindrical drill' used to create the marks had a diameter of ' $0 \mathrm{~m}$. 25'. However, since this translates to the improbable diameter of $25 \mathrm{~cm}$, it is more likely that Quibell erroneously omitted a 0 in the publication, making the actual dimension $2.5 \mathrm{~cm}$.

${ }^{18}$ Lauer and Lacau, La pyramide à degrés V, 98.
}

Fig. 6 Netjerikhet seal impression (6). An improved reproduction by Klasens of a seal impression previously depicted in Firth and Quibell, The Step Pyramid 1, 141 (fig. 21) (courtesy of the Egypt Exploration Society).

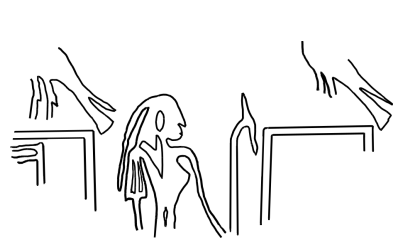

Transliteration: Hr.w Ntr[ $[(j)-\underline{h} . t]$ Hr.w [Ntr(j)-h.t. Translation:

Horus Netjerikhet Horus Netjerikhet

Fig. 7 Netjerikhet seal impression (8). An improved reproduction by Klasens of a sealing previously depicted in Firth and Quibell, The Step Pyramid 1, 141 (fig. 19) (courtesy of the Egypt Exploration Society).

it is probable that different seals with varying end diameters were stamped on different clay fragments from the Northern Galleries. Future investigations of the clay sealings, (presumably held in the Saqqara artefact magazines or the Cairo Museum), should determine the quantity of seals that were rolled and punched on the yellow clay fragments from the Northern Galleries.

During the First and Second Dynasties, large jar sealings of type G2 were frequently incised with grooves, holes, and abstract drawings. ${ }^{19}$ End-stamping of cylinder seals ${ }^{20}$ ap-

${ }^{19}$ W. B. Emery, Great Tombs of the First Dynasty, III (MEES 47; London, 1958), pl. 84; I. Regulski and J. Kahl, 'Gesiegelte Objektverschlüsse aus dem Grab des Ninetjer in Saqqara', MDAIK 66 (2010), 225-7; I. Regulski, 'Early Dynastic Sealing Practices as a Reflection of State Formation in Egypt', in: M. Ameri, S. K. Costello, G. Jamison, and S. J. Scott (eds), Seals and Sealing in the Ancient World: New Approaches to Glyptic Studies (Cambridge, 2018), 263-4.

${ }^{20}$ M. Bárta, A. Bezděk, V. Černý, S. Ikram, P. Kocár, R. Křivánek, M. Kujanová, P. Pokorný, C. Reader, Z. Sůvová, and P. Vlčková, Abusir XIII: Abusir South 2: tomb complex of the Vizier Qar, his Sons Qar Junior and Senedjemib and Iykai (Prague, 2009), 246; Nolan, Sealings, 143. 


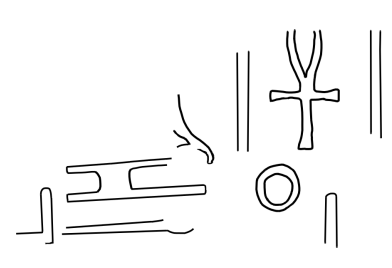

Transliteration:

$H r[\ldots][\underline{c} \underline{d}-] m r^{9}$

nh $[\ldots] N \mathrm{Nhn}^{10}$

Translation:

Horus [...] $\underline{\mathbf{d}}-\mathrm{m} r$

administrator

Living [...] Nekhen

Fig. 8 Netjerikhet seal impression (9). This sealing may be a palimpsest of different impressions from the same or different seals. Note similarity of signs under ankh with those found at the bottom of Figure 3 (courtesy of the Egypt Exploration Society).

pears to have superseded these marking practices in the Old Kingdom. ${ }^{21}$ The punched and sealed pieces of clay from the Northern Galleries in the Third Dynasty Step Pyramid complex may represent the earliest known examples of this sealing practice. Quibell mentioned that the punched clay from the Northern Galleries was impressed with a seal of Netjerikhet. ${ }^{22}$ The practice of end-stamping sealings may therefore have been introduced in the Third Dynasty during Netjerikhet's reign. However, if the Khasekhemwy sealings from the Northern Galleries are also end-stamped, the stamping practice would date to the end of the Second Dynasty. Further investigations of the Northern Gallery sealings should determine whether any Khasekhemwy fragments bear the traces of end-stamped cylinder seals.

The presence of Khasekhemwy sealings in the Northern Galleries likely indicates that this substructure pre-dates the reign of Netjerikhet and belongs to an earlier monument. ${ }^{23}$ Aboveground granaries were subsequently erected over the subterranean Northern Galleries during the last building phase of Netjerikhet's Step Pyramid complex. $^{24}$ The presence of sealings of Net-

${ }^{21}$ M. Verner, P. Posener-Kriéger, and P. Jánosi, Abusir III: the pyramid complex of Khentkaus (Prague, 2001); M. Verner, V. G. Callender, and E. Strouhal, Abusir VI: Djedkare's family cemetery (Prague, 2002); Bárta et al., Abusir XIII; Nolan, Sealings; Digital Giza, $<$ http://giza.fas.harvard.edu/> accessed 2018.07.15.

${ }^{22}$ Firth and Quibell, The Step Pyramid 1, 119.

${ }^{23}$ I. Regulski, 'Investigating a new Dynasty 2 necropolis at South Saqqara', BMSAES 13 (2009), 228.

${ }^{24}$ R. Stadelmann, 'Die Oberbauten der Königsgräber jerikhet in the underground galleries also indicates these were reused for Netjerikhet's burial. It has not previously been explained why a subterranean funerary 'granary' was present on the Saqqara plateau prior to the construction of the Step Pyramid complex for Netjerikhet.

An examination of the other set of preNetjerikhet underground galleries integrated into the Step Pyramid complex may provide evidence for the original purpose of the Northern Galleries. The Western Galleries are located near the magazines of the Northern Galleries (see fig. 11). The currently known layout of the Western Galleries (fig. 12) closely resembles the galleries of the Second Dynasty ruler Hotepsekhemwy at Saqqara (fig. 13). The recently excavated royal grave of Ninetjer at Saqqara also has a similar layout. ${ }^{25}$ Consequently, it has been theorized the Western Galleries were originally the burial place of a Second Dynasty ruler. ${ }^{26}$

The large cluster of side galleries closest to the stairway entrance in the subterranean Second Dynasty royal burials at Saqqara has been identified as storage space by a recent study of the Ninetjer complex. ${ }^{27}$ Comparing the grey shaded areas in fig. 12 to those illustrated in fig. 13 shows the storage area is clearly unfinished in the Western Galleries. Lauer states the ceilings of the Western Galleries are often unstable due to the argillaceous nature of the bedrock. ${ }^{28}$ Thus, it is possible the 'magazines' of the Western Galleries remained unfinished due to the fragility of the bedrock in that sector. The Northern Galleries, found to store grain, fruit, and possibly bread, ${ }^{29}$ may have been created as an ersatz storage area for the Western Galleries complex. Funerary gra-

der 2. Dynastie in Sakkara', in: P. Posener-Kriéger (ed.), Mélanges Gamal Eddin Mokhtar, vol. II (BdE 97; Cairo, 1985), 303.

${ }^{25}$ C. M. Lacher-Raschdorff, Das Grab des Königs Ninetjer in Saqqara: architektonische Entwicklung frühzeitlicher Grabanlagen in Ägypten (AVDAIK 125; Wiesbaden, 2014), plan 4.

${ }^{26} \mathrm{R}$. Stadelmann, Die ägyptischen Pyramiden: vom Ziegelbau zum Weltwunder (Mainz, 1991), 49; A. Dodson, The pyramids of ancient Egypt (London, 2003), $41-2$.

${ }^{27}$ Lacher-Raschdorff, Ninetjer, 151, abb. 39.

${ }^{28}$ Lauer, La pyramide à degrés I, 181.

${ }^{29}$ Lauer, La pyramide à degrés III, 184. 


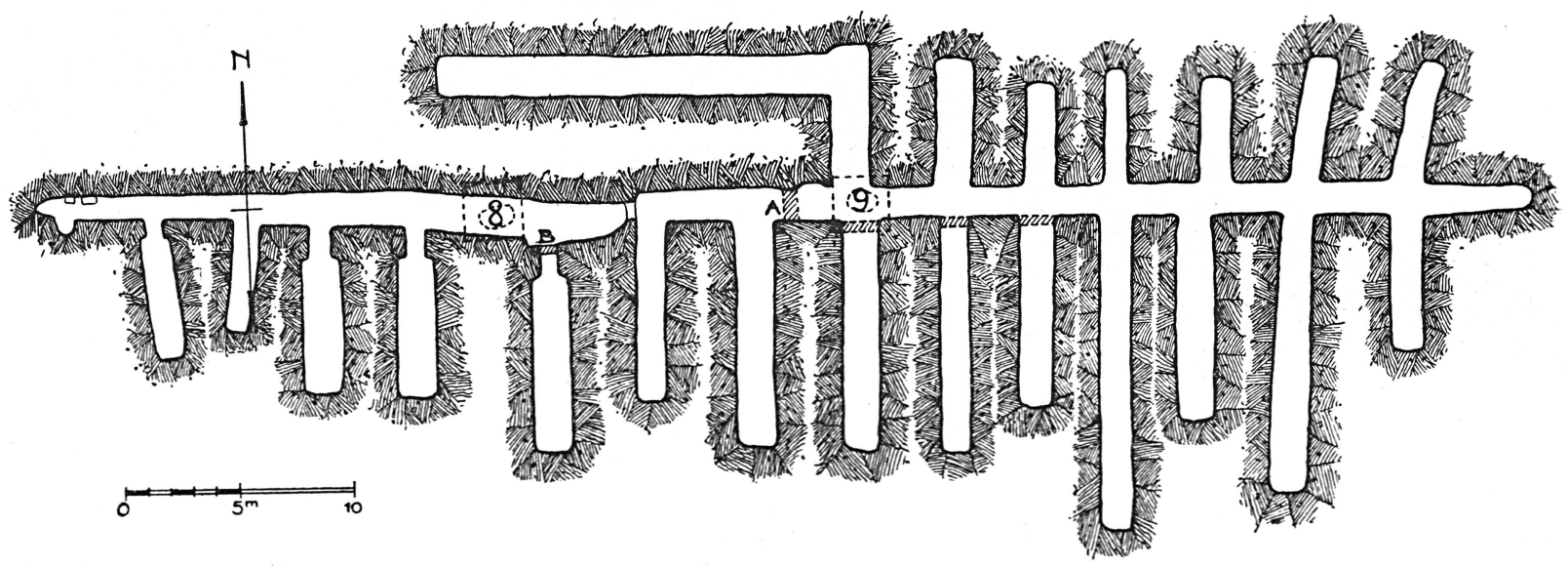

Fig. 9 Northern Galleries of the Step Pyramid. Note the blocking walls labelled 'A' and 'B' (from Lauer, La pyramide à degrés I, 184, fig. 208).

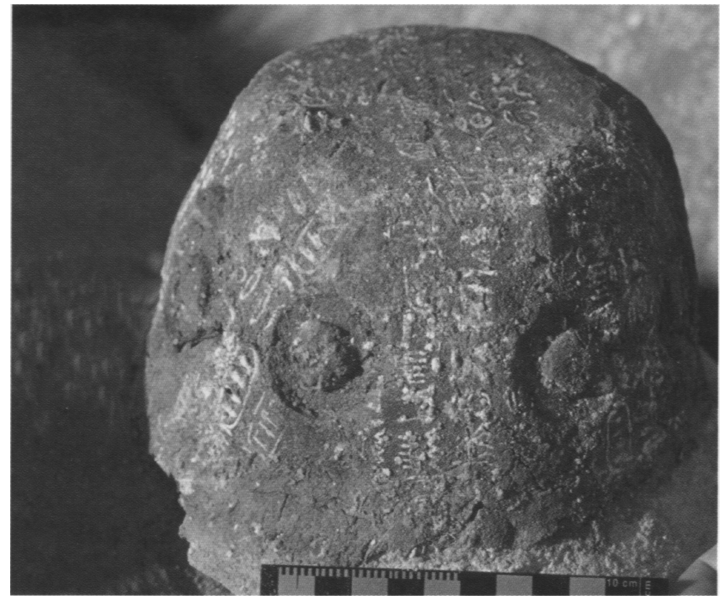

Fig. 10 Jar sealing found in the tomb of Qar Junior at Abusir, impressed with circular marks of a seal end punched into the surface as well as impressions of a seal (courtesy of Miroslav Bárta. From Bárta et al., Abusir XIII, 349). naries were already attested in the First Dynasty Mastaba 3038 on the Saqqara Plateau. ${ }^{30}$ Thus, the Northern Galleries were likely not an innovation, but represent an extension of a preexisting funerary concept.

The identity of the royal individual for whom the Western Galleries were created remains unclear. It has been proposed that Khasekhemwy was buried in the Saqqara Western Galleries instead of his Abydos grave. ${ }^{31}$ Khasekhemwy's possible predecessor, Sekhemib, ${ }^{32}$ could also have been buried in a complex that included the Western and Northern Galleries. The administration of Khasekhemwy would likely have been responsible for preparing the final burial of his predecessor. This could explain the presence of seal impressions bearing Khasekhemwy's name in the Northern Galleries.

To determine which hypothesis is more plausible, future investigations should focus on examining previously retrieved stone vessels from the Western Galleries ${ }^{33}$ for possible royal inscriptions. Further excavations in the Western and Northern Galleries may also clarify the probable original 'ownership' of these substruc-

\footnotetext{
${ }^{30}$ W. B. Emery, Great Tombs of the First Dynasty, I (Cairo, 1949), 82-3.

${ }^{31}$ G. Dreyer, 'Khasekhemwy', in: R. S. Bagnall, K. Brodersen, C. B. Champion, A. Erskine, and S. R. Huebner (eds), The Encyclopedia of Ancient History (Oxford, 2013), 3743.

${ }^{32}$ J. Kahl, 'Inscriptional Evidence for the Relative Chronology of Dyns. 0-2', in: E. Hornung, R. Krauss, D. Warburton, and M. Eaton-Krauss (eds), Ancient Egyptian Chronology (HdO 83; Leiden, 2006), 105.

${ }^{33}$ Firth and Quibell, The Step Pyramid 1, 71.
} 


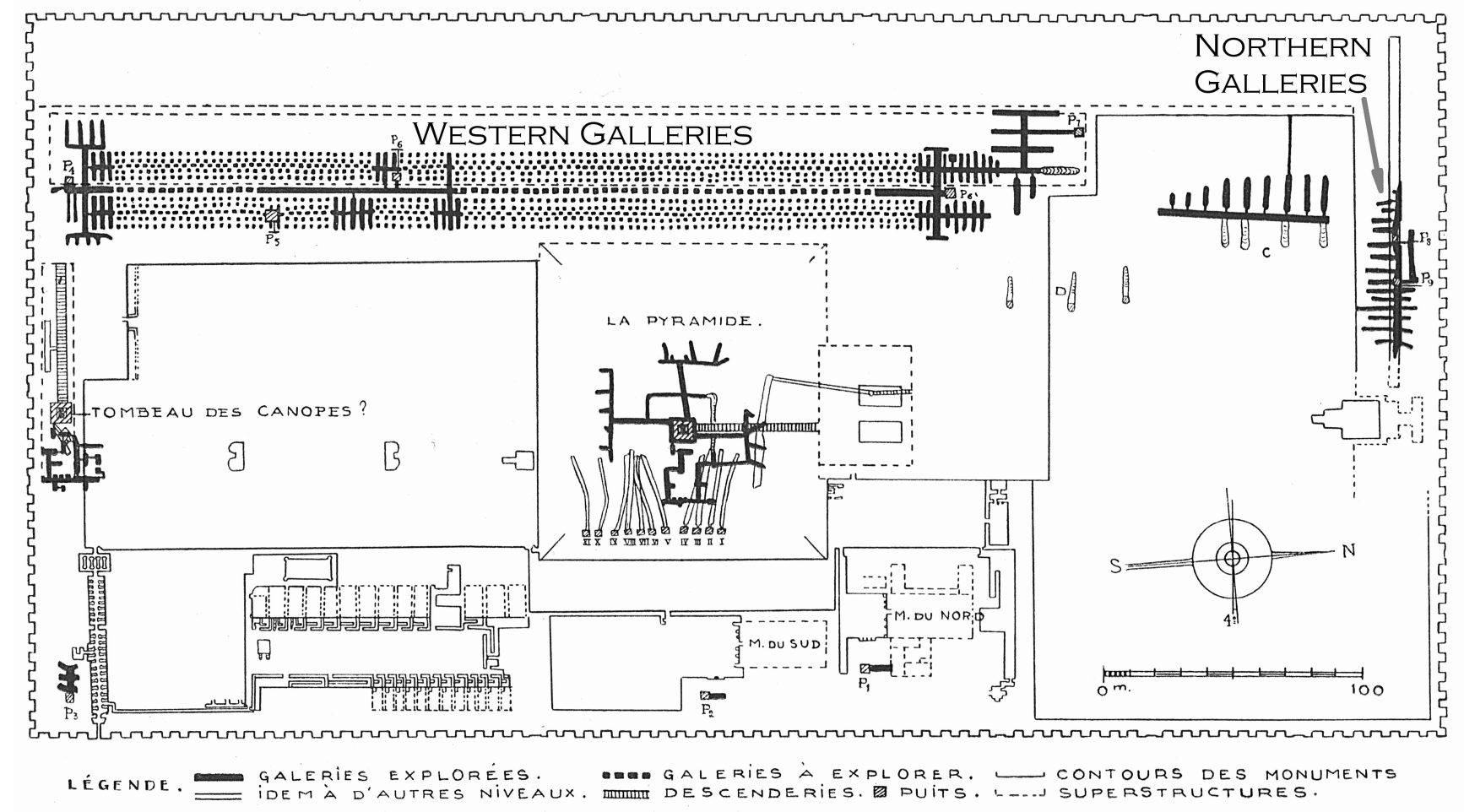

Fig. 11 Map of Step Pyramid complex (modified from Lauer, La pyramide à degrés III, pl. XXII).

tures.

\section{Seal impression motifs: possible parallels}

Of the sealings drawn by Klasens, two impressions have possible parallels in seal images from the Third Dynasty mastabas at Beit Khallaf. Khasekhemwy seal impression (5) may be paralleled by seal image 7 from Beit Khallaf mastaba $\mathrm{K} 5$, or $\mathrm{Ne} / \mathrm{Be} / 43$ in Kahl's classification. ${ }^{34}$ However, Kahl's volume also specifies that the column of signs containing the $n$ Nhn as originally drawn by Garstang ${ }^{35}$ is presently illegible. Consequently, Khasekhemwy seal impression (5) may be another instance of seal image $\mathrm{Ne} / \mathrm{Be} / 43$, but this cannot be confirmed in the absence of additional sealings bearing this seal image.

Several parallels can be drawn between Netjerikhet seal impression (8) and Beit Khallaf seal image 8 from K 5, or Ne/Be/42 in Kahl's classification. ${ }^{36}$ As shown in fig. 14, the sleeve detail and long hair of the female deity depicted

\footnotetext{
${ }^{34} \mathrm{Kahl}$ et al., Inschriften der 3. Dynastie, 36.

${ }^{35} \mathrm{~J}$. Garstang and K. Sethe, Maḥ̂asna and Bêt Khallâf (London, 1903), pl. XXVI.7.

${ }^{36} \mathrm{Kahl}$ et al., Inschriften der 3. Dynastie, 36.
}

in Netjerikhet seal impression (8) clearly parallels details of the goddess figure depicted on $\mathrm{Ne} / \mathrm{Be} / 42$. The female figures on the Step Pyramid sealing and the Beit Khallaf seal image also both hold a wis sceptre (compare fig. 8 with fig. 15).

The female deities on the Step Pyramid sealing and the Beit Khallaf seal image do not wear any crowns that might aid in identifying which goddess is depicted. The figure depicted on seal image $\mathrm{Ne} / \mathrm{Be} / 42$ was identified by Kaplony as a western nome deity, ${ }^{37}$ likely because of a reference to a western nome in the sealing inscription. ${ }^{38}$ However, the recent discovery of a very well preserved partial impression depicting the goddess Seshat from Abydos has demonstrated that the name of a god or goddess is likely to have been inscribed directly above the head of the deity on early seals. ${ }^{39}$ Since this inscription does not survive on Netjerikhet seal impression

${ }^{37} \mathrm{P}$. Kaplony, Die Inschriften der Ägyptischen Frühzeit, 2 (苂 2; Wiesbaden, 1963), 1137.

${ }^{38} \mathrm{Kahl}$ et al., Inschriften der 3. Dynastie, 36-7.

${ }^{39}$ G. Dreyer, A. Effland, U. Effland, E.-M. Engel, R. Hartmann, U. Hartung, C. Lacher, V. Müller, and A. Pokorny, 'Umm el-Qaab: Nachuntersuchungen im frühzeitlichen Königsfriedhof: 16./17./18. Vorbericht', MDAIK 62 (2006), 119. 


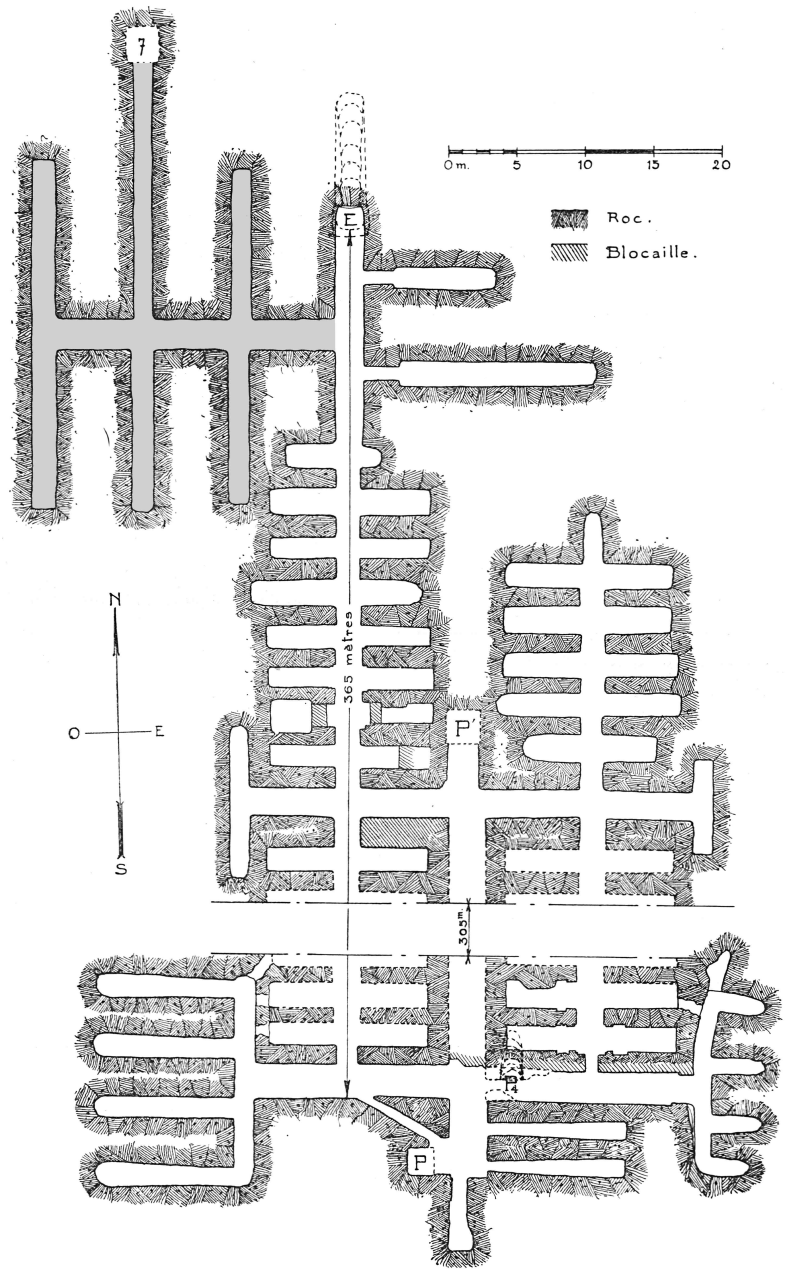

Fig. 12 Map of the explored sections of the Western Galleries in the Step Pyramid complex. Storage areas are shaded grey (modified from Lauer, La pyramide à degrés I, fig. 206).
(8) (fig. 7) or on the Beit Khallaf seal image (fig. 15), it is not possible to further speculate on the identity of the goddess in either case. The lack of Horus-falcons on top of the Beit Khallaf seal image may simply be due to their erasure on the Khallaf clay sealings. A definitive verdict on whether the Step Pyramid sealing and the Beit Khallaf seal image are identical would require the discovery of another sealing fragment from the Step Pyramid whose impression preserves the bottom part of the serekh facade, which is not visible on the Netjerikhet seal impression (8). This part of the facade varies from seal image to seal image ${ }^{40}$ and can be used as a diagnostic element (for instance, compare the different appearance of the facade in fig. 6 to the facades shown on Beit Khallaf Ne/Be/42 in fig. 15).

In Netjerikhet seal impression (6), the fragmentary inscription of the ibis next to the $p r$ sign (see fig. 6) may originally have read pr.w (n)sw pr.w dšr k’n.w, or 'Royal property management Red House, vineyard'. ${ }^{41}$

Finally, Netjerikhet seal impression (5), shown in fig. 5, appears to depict a quail chick inside a box or a $p r$ enclosure, as is the case for the ibis depicted inside an enclosure on previously published Netjerikhet sealings from the Northern Galleries. ${ }^{42}$

While parallels can be drawn between some seal images attested at Beit Khallaf and the Saqqara Northern Galleries sealings published here, little evidence for direct parallels between the seal images can be found at present. Future excavations may help to establish whether the sealed artefacts delivered to and created at the Step Pyramid were different from those shipped to Beit Khallaf, or whether there was an overlap in the administration supplying the burials at both sites.

\section{Conclusion}

Re-examining the available evidence for the appearance and find location of the previously unpublished sealings drawn by A. Klasens has

\footnotetext{
${ }^{40}$ Regulski, A Palaeographic study, 552-9.

${ }^{41}$ Kahl et al., Inschriften der 3. Dynastie, 20-1.

${ }^{42}$ Lauer and Lacau, La pyramide à degrés V, 98 (figs $182-3)$.
} 


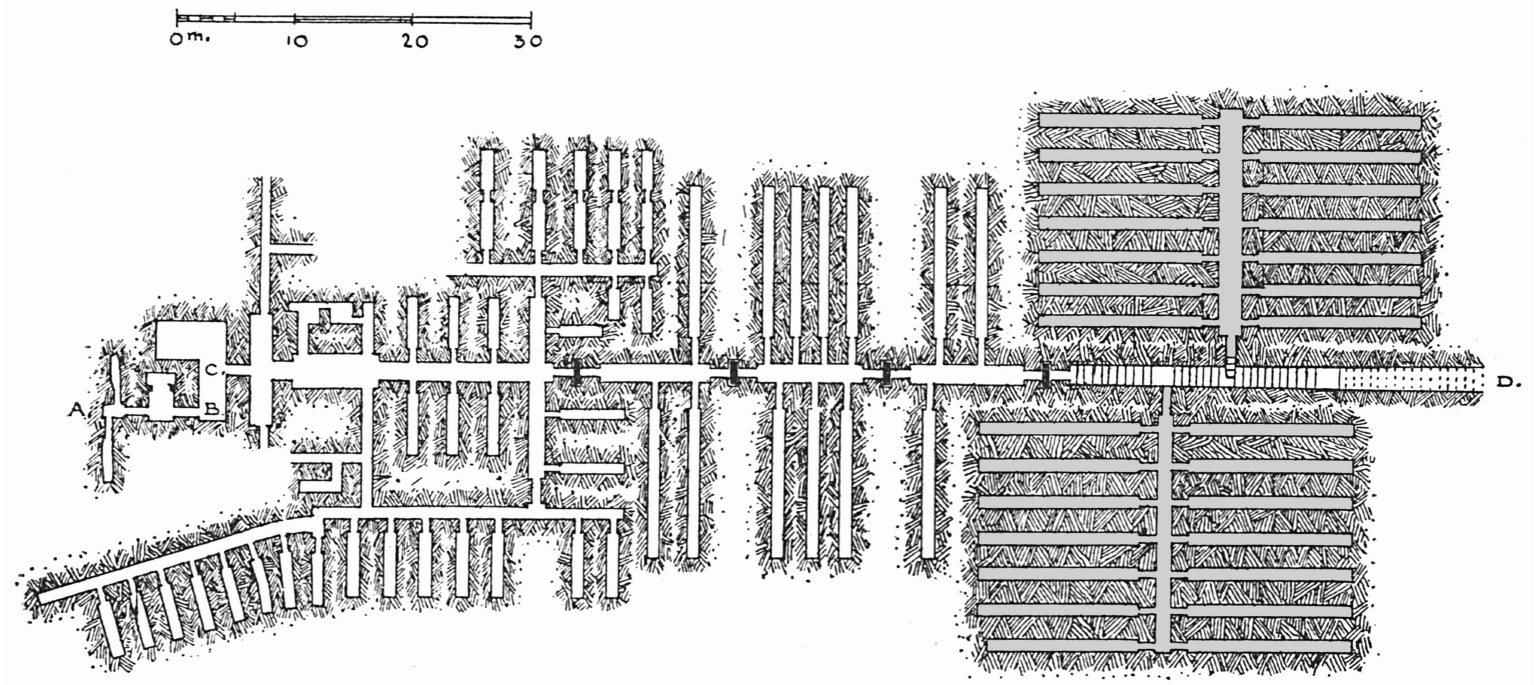

Fig. 13 Map of galleries of the tomb of Hotepsekhemwy at Saqqara. Storage areas are shaded grey (modified from Lauer, La pyramide à degrés I, fig. 2).

shown that the sealings from the Northern Galleries of the Step Pyramid represent the earliest evidence for 'punched' sealings known to date. This provides new perspectives on the origins of an Old Kingdom administrative practice. For the first time since the discovery of the Northern Gallery sealings, a complete re-evaluation of their find context has been conducted. The Northern Galleries can now be posited to form part of the same Second Dynasty complex as the Western Galleries. The original superstructures of this complex were likely razed when the Step Pyramid was built. At least one seal impression, Netjerikhet seal impression (8), was also found to closely parallel a seal image from Beit Khallaf. However, further excavations and studies of previously recovered material are necessary to determine whether identical seals were used on sealings found at the Step Pyramid and Beit Khallaf.

By re-examining archival material, this paper has re-evaluated the significance of the Northern Galleries sealings, and the earliest known incidence of an Old Kingdom sealing practice has been identified. A new theory on the possible origins and purpose of the Second Dynasty funerary substructures under the Step Pyramid complex has also been developed.

Acknowledgment: The author would like to thank the EES for their permission to reproduce Klasens' drawings.

Funding: The author(s) received no financial

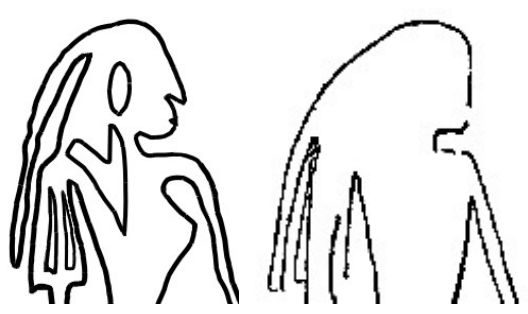

Fig. 14 Left image: Netjerikhet seal impression (8), detail of head and torso (courtesy of the Egypt Exploration Society). Right image: Beit Khallaf $\mathrm{Ne} / \mathrm{Be} / 42$, detail of head and torso.
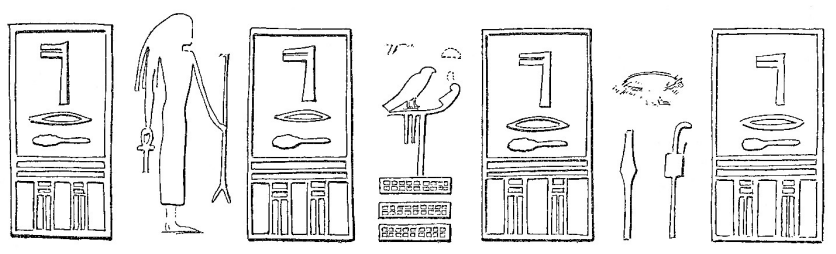

Fig. 15 Beit Khallaf Ne/Be/42, from Garstang and Sethe, Maĥâsna and Bêt Khallâf, pl. XXvi.8 (Not to scale).

support for the research, authorship, and/or publication of this article.

Author biography: Tatjana Beuthe completed her PhD at University College London in 2016. Her research centres on administrative systems, manufacturing industries, and burial customs in Egypt, Sudan, and the Near East. 